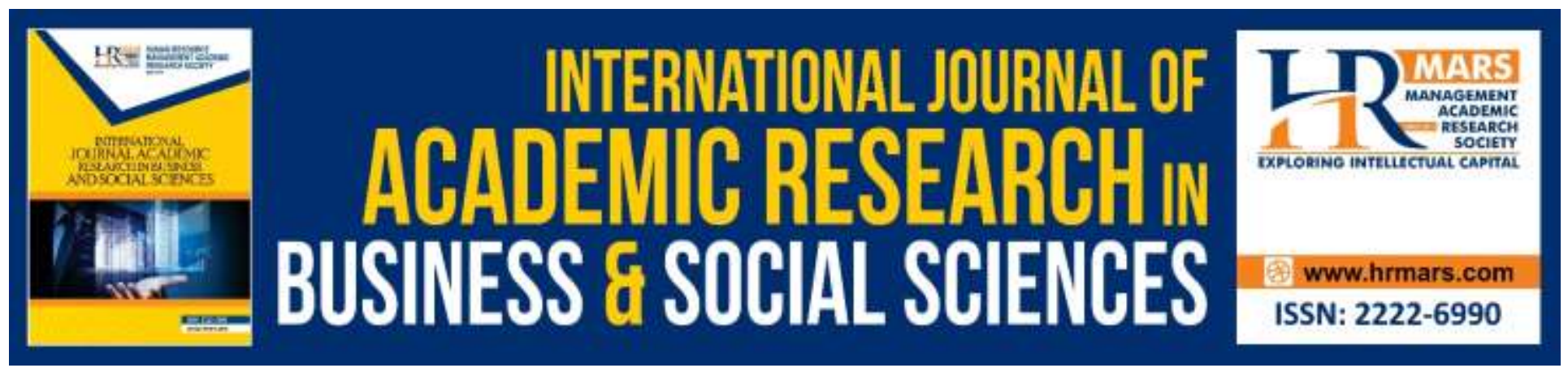

\title{
Overconfidence Bias in Working Capital Management and Performance of Small and Medium Enterprises: The Perspectives of Ghanaian SME Managers
}

Jeff Lamptey, Asri Bin Marsidi, Bilyaminu Usman, Ashemi Baba Ali, Wasilu Suleiman

To Link this Article: http://dx.doi.org/10.6007/IJARBSS/v10-i6/7372

DOI:10.6007/IJARBSS/v10-i6/7372

Received: 08 April 2020, Revised: 26 May 2020, Accepted: 17 June 2020

Published Online: 29 June 2020

In-Text Citation: (Lamptey et al., 2020)

To Cite this Article: Lamptey, J., Marsidi, A. Bin, Usman, B., Ali, A. B., \& Suleiman, W. (2020). Overconfidence Bias in Working Capital Management and Performance of Small and Medium Enterprises: The Perspectives of Ghanaian SME Managers. International Journal Academic Research in Business and Social Sciences, 10(6), 751-765.

Copyright: (c) 2020 The Author(s)

Published by Human Resource Management Academic Research Society (www.hrmars.com)

This article is published under the Creative Commons Attribution (CC BY 4.0) license. Anyone may reproduce, distribute, translate and create derivative works of this article (for both commercial and non-commercial purposes), subject to full attribution to the original publication and authors. The full terms of this license may be seen at: http://creativecommons.org/licences/by/4.0/legalcode

Vol. 10, No. 6, 2020, Pg. 751 - 765

http://hrmars.com/index.php/pages/detail/IJARBSS

JOURNAL HOMEPAGE

Full Terms \& Conditions of access and use can be found at http://hrmars.com/index.php/pages/detail/publication-ethics 


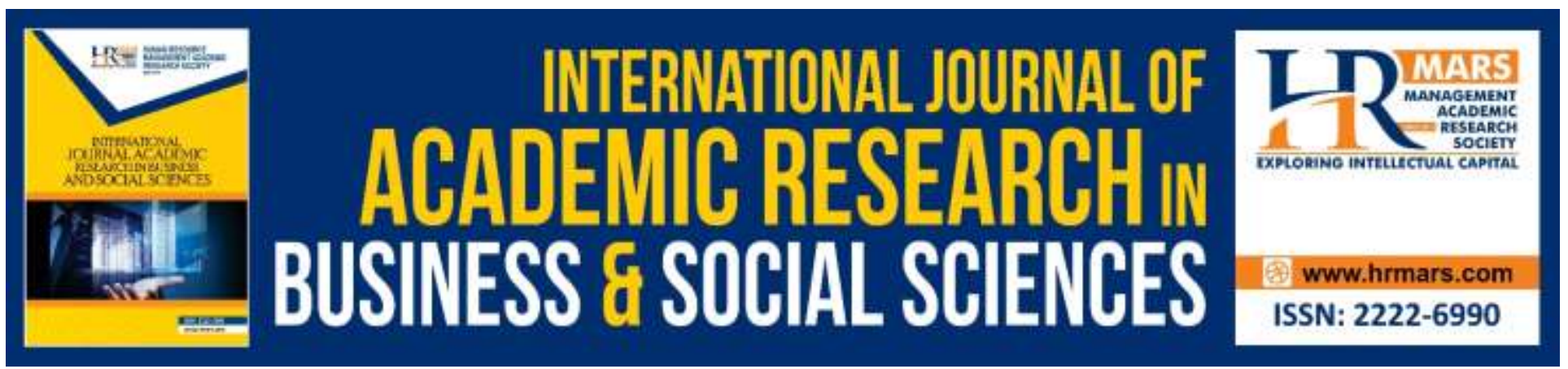

\title{
Overconfidence Bias in Working Capital Management and Performance of Small and Medium Enterprises: The Perspectives of Ghanaian SME Managers
}

\author{
Jeff Lamptey, Asri Bin Marsidi, Bilyaminu Usman \\ Faculty of Economics and Business, Universiti of Malaysia Sarawak \\ Email: jefflampt@gmail.com,maasri@unimas.my, bilyaminu1974@gmail.com \\ Ashemi Baba Ali \\ Department of Economics, University of Maiduguri, Borno State, Nigeria. \\ Email: ashemites@yahoo.com

\section{Wasilu Suleiman} \\ Department of Business Administration, Bauchi State University Gadau. \\ Email: wasilusuleiman@yahoo.com
}

\begin{abstract}
Although managerial overconfidence is receiving substantial attention in economic analysis, explanations so far mostly focused on corporate executives and corporate investment and financing decisions. This study investigates SME managers (owners) overconfidence behavioral bias in working capital management and performance. A qualitative case study was employed to explore the perspectives of 35 SMEs managers from trading and manufacturing firms. Data were obtained through Semi- structured interviews. Based on the thematic analysis, the study found superior financial ability, perfect industry knowledge and optimism in business success to be SMEs overconfidence behaviors and their influence on working capital management and performance resulted in aggressive working capital investment and financing and expected higher performance. Specifically, overconfident SME managers is more likely to overinvest in working capital inventory for expected higher profits if they have access to sufficient internal capital. However, they are less likely to invest more in firms with substantial working capital investment in inventories if expected sales revenue are below expectation. We argued that, overconfident matters so it is not enough to study working capital management and performance of SMEs without considering manager's biases.
\end{abstract}


INTERNATIONAL JOURNAL OF ACADEMIC RESEARCH IN BUSINESS AND SOCIAL SCIENCES Vol. 10, No. 6, June, 2020, E-ISSN: 2222-6990 @ 2020 HRMARS

Keywords: Overconfidence bias, SMEs Managers, Working Capital Management, Performance, Ghanaian SMEs, Manufacturing and Trading, Qualitative Study.

\section{Introduction}

Working capital management has attracted scholars' attention concerning how SME make working capital investment decisions to maximize profit. Although it is believed that when firms apply modern finance practices, they can optimize their investments, but smaller businesses are yet to fully embrace these practices in working capital management. Instead, most SMEs adopt subjective approach (Khoury et al., 1999; Howorth \& Westhead, 2003) and do not apply working capital models (Filbeck, \& Lee, 2000), But rather managers rely on their experiences in managing working capital (Pham, 2013, p.88; Bandara \& Rathnasiri, 2016). Yet, researchers have still not look into SMEs managers' perspectives on working capital management. Thus, given the fact that subjective decision is a typical case of behavioral bias, and noting that SMEs managers (owners) are the top executives, they are more likely exhibiting overconfident behavioral biases in working capital management and performance.

Overconfidence research spans many disciplines and is one of the main managerial biases influencing corporate decision outcomes. Overconfident people unrealistically believe in their abilities, precision of knowledge and personal information to be better. This belief induces managers to overestimate firm value and underrate their failure. Although managerial overconfidence influence outcome of corporate policies (Ben-David, et al., 2010), how it influences short term financial management is unknown. Till date literature on overconfidence in working capital management is lagged behind. What we know is overconfident CEO and CFO and long-term decisions (Malmendier \& Tate, 2015; Panpan, \& Xindong, 2017). However, what is unclear yet is how overconfident SME managers influence working capital management and performance, despite that the fact overconfident people exist in every professional.

In Ghana, SME's working capital management practices are less formalized. Managers (owners) rely on their experience and interest to make working capital decision due to their weakness in formal financial practices. That means those with exceptional personal traits, emotional and cognitive abilities can influence working capital management. And managers with such abilities and experiences to identify new business opportunities tend to be more optimistic about their future growth than their peers. So, they tend to commit more financial resources into working capital and new business projects in order to maximize higher sales revenue and returns, making them believe that they control the expected cash flows or their performance and thus be committed to their decisions. Therefore, the aims of this research are follows:

- To explore overconfident behaviors of SMEs managers (owners).

- To investigate influence of overconfident SME managers working capital management and performance.

Numerous studies found overconfident people's subjective decision result in systematic biases. Managerial overconfidence means overestimation of future performance. Malmendier and Tate, 
INTERNATIONAL JOURNAL OF ACADEMIC RESEARCH IN BUSINESS AND SOCIAL SCIENCES Vol. 10, No. 6, June, 2020, E-ISSN: 2222-6990 @ 2020 HRMARS

(2015) opined that overconfidence occurs when top managers believe their firms assets are underpriced by the market, which move them to overestimate positive NPV of the projects.

Such managers personally choose projects that can bring more returns to increase the company's future share value. In this line, Malmendier and Tate, (2008) find overconfident CEOs overinvest in capital expenditure and mergers and acquisitions; Innovation (Galasso \& Simcoe, 2011). Also, overconfident CEOs of RIET acquire more assets and do not want to sell them if they have enough "discretionary cash" (Eichholtz, \& Yonder, 2015). Meanwhile, Ben-David, Graham \& Harvey, 2007) prove that overconfident CFOs invest more in long term asset using low discount rate thereby overestimating the cash flows to their project.

Essentially, overconfident CEOs prefer internal funds and overinvest if only the funds are enough. However, they curtail investment for lack of funds and would not issue new equities due to the perceived undervaluation of firm stock, fear of dilution of shareholdings and costly debt. But, Barros and Silveira (2009) find optimistic managers use higher debt ratio in the firm's capital structure, increasing the costs of financial distress. This result was contradicted by Malmendier, Tate and Yan (2011) who found that optimistic CFOs use less equity financing and more debt financing when the financial deficit of the firm is high.

In term performance, Eichholtz and Yönder, (2015) indicate REIT CEO Overconfidence produce negative returns while Roll, (1986); Hackbarth, (2006) report that underestimation risk results in lower performance. Meanwhile aggressive managers produce higher value than conservative managers. Moreover, mild overconfidence managers had higher return on investment, unlike highly overconfidence CEO who had a lower return due to excessive overinvestment (Bertrand \& Schoar, 2003).

Overconfidence is a well-known bias in the field of psychology. The issues this theory addresses are how people assess their knowledge and skills, ability relative to others and estimate their personal information and outcomes of future events. It emerged that people are overconfident when they overestimate their ability to be better than average (Larwood \& Whittaker, 1977; Svenson, 1981). The tendency for people to believe they can better control outcome of events makes them overconfident caused by illusion of control. This bias is exacerbated by excessive optimism for assigning high (low) probabilities to good things (unfavorable events) following previous experience (Weinstein, 1980; Cooper et al., 1988). Likewise, mis-calibration triggers overconfidence bias, arising from people tendency to overestimate their accuracy of knowledge, ability and information in order to while estimating future outcomes.

By implication, overconfident managers overestimate their ability above average and overly optimistic about the outcomes financial decisions they control (Malmendier, et al., 2011). Thus, overconfident managers overestimate returns above the average performance to the outcome variable of their decisions and underestimate likelihood of bad firm performance.

Related to economic decisions, overconfident managers overinvest in order to earn high returns on investment and thus underestimate the riskiness of their cash flows. Moreover, overconfident CEOs 
INTERNATIONAL JOURNAL OF ACADEMIC RESEARCH IN BUSINESS AND SOCIAL SCIENCES Vol. 10, No. 6, June, 2020, E-ISSN: 2222-6990 @ 2020 HRMARS

uses more internal less equity while CFOs use more debt and less equity depending on the objective and expected outcome similarly overconfident investors buy more assets for higher gains. But how overconfident SMEs manager influence working capital management and performance is yet to be addressed.

\section{Methodology and Research Design}

Our study employs qualitative inquiry approach to gain deeper insight into the of nature of overconfident bias of managers. And due to the nature of overconfidence, we adhered to Strauss and Corbin (1998, p.11) suggestions that "qualitative methods can be used to obtain the intricate details about phenomena such as feelings, thought, processes, and emotions that are difficult to extract or learn about through more conventional methods".

Our research design is a single case study that enables researchers to study one particular phenomena (Yin, 1994; Stake,2000). This case study allows people to "develop in-depth description and analysis of cases" and develop a "better theory" (Siggelkow, 2007; Dyer and Wilkins, 1991). As argued by Dyer and Wilkins (1991) that "single case studies are better than multiple cases in terms of depth and theorizing" by allowing a researcher to query existing theoretical relationship and evolve new theory through deeper examination of the phenomenon.

\section{Participants and Sample Selection}

We chose managers of small and medium enterprises (SMEs) because of aims of study. Purposive sampling method and snow balling techniques were selected over non-probability sampling due to nature of phenomena and research question requiring different perspectives. Recruitment of participants were based on availability, willing to participate, ability to communicate experience in local dialects and others (Spradley, 1979 cited in Etikan, et al., .2016). These techniques provided us the opportunity to obtain the needed diverse information. The selection of managers took off after faculty approved this research. Tentatively, fifty-five (55) participants confirmed their participation and explanatory letters and consent forms were emailed them for confirmation. Our final participants are thirty-five (35) managers based on saturation point.

\section{Data Collection and Instrument}

Data were collected through semi structured interviews as described by Fontana and Frey $(2000 ; 645)$ to be "one of the most powerful way in which we try to understand our fellow human being". Telephone interview was used because it is valid means of collecting qualitative data (Cachia \& Millward, 2011; Glogowska et al., 2011, Trier-Bieniek, 2012; Vogl, 2013). This method is much convenient like face to face- interviews (Deakin \& Wakefield ,2014). However, Cachia and Millard (2011) argue that telephone interviews provide maximum privacy and comfort to participants to engage in lengthy conversation. In addition, it also offers the researcher opportunity to reach participants who hardly can be contacted personally due to business commitments (Fenig et al.,1993). Overall, these flexibilities stimulate interest of participants and motivate interviewees to participate actively in the interviews (Cachia \& Millward, 2011).

The interviews focused on overconfidence behaviors in working capital management and performance guided by interview protocols. The in-depth interview enabled us capture actual 
INTERNATIONAL JOURNAL OF ACADEMIC RESEARCH IN BUSINESS AND SOCIAL SCIENCES

Vol. 10, No. 6, June, 2020, E-ISSN: 2222-6990 @ 2020 HRMARS

behaviors of managers through opening ended conversion, clarification, probing, reminders and quick recap (Shelden et al.2010; Burke \& Miller, 2001; Glogowska et al., 2011). Interviews were recorded, transcribed and analyzed.

\section{Data Analysis}

Data were analyzed using Thematic Data technique to identify overconfident behaviors of SMEs managers and their influence on working capital management and performance. In search themes, we read and familiarized with transcribed data and gained understanding of meanings of the data. Data were coded by making notes, identifying segment that are potentially related to the findings or part of research questions which can be meaningful word or group of words used by participants to describe their experience (Merriam,2009). We used theoretical coding process to address research questions and each segment of data that was relevant was coded as exact word of participants, concept from literature or researcher own construct because we did have preset codes so open coding process was applied to search initial codes.

All codes were entered into NVIVO software version 12 pro for categorization of initial themes which were reviewed and modified into final theme being main findings on the descriptive accounts of managers' overconfident bias in working capital and performance in our concept development map in Figure 1.

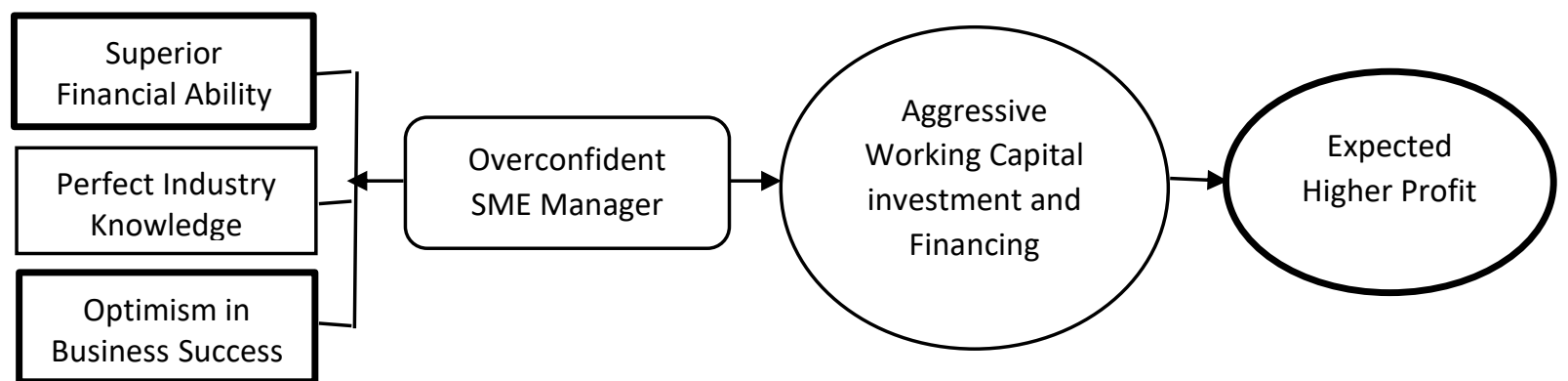

Figure 1: Concept Mapping of Findings of Overconfident SME Managers on Working Capital Management and Performance

\section{Result}

\section{Overconfident Behaviors of SME Managers}

We found SMEs managers to be overconfident which emerged from superior financial ability, complete perfect industry knowledge and optimism in business success. And their influence resulted in aggressive working capital investment and financing, and expected higher performance. Superior financial ability portrays participants to be better than their counterparts while assessing their financial ability. Based on the responses, we categorized managers as high financial ability, moderate financial ability or low financial ability.

Managers with high financial ability have extremely high or extremely better financial knowledge. These managers are highly experienced with at least 15 years of practice and may be highly successful 
INTERNATIONAL JOURNAL OF ACADEMIC RESEARCH IN BUSINESS AND SOCIAL SCIENCES Vol. 10, No. 6, June, 2020, E-ISSN: 2222-6990 @ 2020 HRMARS

managers. That means highly success SMEs managers may have high level of financial knowledge and understand the industry practices better. A case in point is participant 5 who stated that:

"... My financial ability is much, much better. I have been in the second hand clothing business for 17 years now and have made several financial decisions which yielded positive results despite the numerous industry challenges which other firms could not survive. I have been able to build a successful business and still growing. In addition, participant 3, indicated that "my financial ability is extremely higher. Considering my $15 y e a r s$ in the beverage business and the positive impact of my financial decision on the growth and success of this company" Furthermore, participant 32, "my financial knowledge is much, much better. Over the past 17 years in the food and beverage business, I have survived the difficult times which have increased my financial knowledge in diverse ways to build a very viable and reputable business....".

Moreover, managers with moderate financial ability have much better or much higher financial knowledge. Their experiences range from 10 years to 15 years and may have moderate success despite the industry challenges. This finding is corroborated by participant 1 who stated that:

"I believe that my financial ability is much better. I have been in the beverage industry for 10 years now. Implemented several financial strategies that have brought this firm to this position despite the numerous financial challenges and unfriendly business condition. But I am still trying to grow the business to the highest level." Likewise, Participant 15 said: "I believe my financial ability is quite better. Considering my 8years in the rubber and plastic business and how my financial decisions have contributed this modest success despite the ups and downs".

Meanwhile, managers with low financial ability believe theirs were above average and described them as just better or higher than their peers. These managers have experiences spanning 5 to 10 years, indicating they slightly outperform industry average success. Participant 7 said,

"My financial ability is better and I am trying to improve more. I have been able to manage my finances to the best of my ability for the past 9 years to withstand the problems of the agro. processing industry. I am okay with the little progress I have made and I hope to do more". Participant 9, opined that: "my financial knowledge is very high. For 7 years in the retailing business is not a joke. Although the market is tough and challenging, I have not done badly at all, but hoping to achieve more in the future." Moreover, participants 25 stated that "my financial ability is above average. I am 5 years now in the sachet water business and my previous performance is a good sign of better future. Looking at the nature of the market challenges, without this level of financial ability, the firm would not exist by now. On the whole, my success is just average".

By implication, the level of superior financial ability determines participant ability to overcome industry challenges and the level of success. 
INTERNATIONAL JOURNAL OF ACADEMIC RESEARCH IN BUSINESS AND SOCIAL SCIENCES Vol. 10, No. 6, June, 2020, E-ISSN: 2222-6990 @ 2020 HRMARS

Optimism in Business Success: Optimism in business success was another finding of overconfident behavior. This shows SME managers tends to underrate the likelihood of business failure and overrate future business success. But they appear to be highly or moderately optimistic. Highly optimistic managers believe to have extremely high rate of business success than moderately optimistic managers. High optimism may be caused by high level of industry experience, high growth expectation and good past performance. This finding is confirmed by these quotes. Participant 4 stated that:

"....my chances of succeeding are much higher than the likelihood of failure, trust me! I have been in the wholesaling and retailing business for 15 years now and it is still growing. I intend to introduce new products and expand my sales networks across the regions to realize this success". Likewise, participant 18, said that: "I am much more likely to be successful and less likely to fail. I have always wanted to be successful and without this mind set I would not have reached this current position. Considering my industry experience and financial knowledge, I tend to expand the business operations and distribution networks to achieve this success..."

Meanwhile moderate optimistic managers anticipated higher business success due to how they estimate their likelihood success. For instance, participants 16, asserts that:

"....my likelihood to be successful in this business is higher considering the previous performance and 12 years of industry experience. I will open more sales outlets in some districts in Accra. Similarly, Participant 11 responded that: I think that my success rate is higher. It is my belief to be successful in business than to fail. Based on what I have achieved over the last 7 years gives me the assurance to expand my herbal business to other across the regions and beyond. I am sure that I can succeed because of my experience and knowledge..."

This evidence suggest that optimism could be key factor for business success among SMEs. That means managers who may be proactive and have ability to spot future business opportunity and could do well in harsh or uncertain environment.

\section{Influence of SME Loss Aversion on Working Capital Management and Performance}

Overconfident SME managers favored aggressive working capital investment and financing.

Aggressive Working Capital Inventory: The aggressive working capital investment means that SME manager overinvest in working capital inventory for expected higher returns. Overinvestment in inventory is for transactional purposes. This can allow managers to conduct daily operations, meet market demand, increase revenue and increase profit margins. In addition, overinvestment provide accurate signal to customers and guaranteed profit. Managers having more goods are more likely to attract more customers and regularly serve their customers thereby increasing profits. Furthermore, it serves useful competitive tool or strategy to avert the possibility of losing customers to other 
INTERNATIONAL JOURNAL OF ACADEMIC RESEARCH IN BUSINESS AND SOCIAL SCIENCES Vol. 10, No. 6, June, 2020, E-ISSN: 2222-6990 @ 2020 HRMARS

competitors' due inadequate inventories, thereby realizing more profit. For example, participant 6 stated.

"... I prefer to invest more in working capital. I will buy more stock in order to increase production so that I can make more profit. Based on my experience, if I don't have enough goods, the customers go different place to buy goods and this affect my sales and profit. But whenever I have goods, my sales and profit margins increase. And I am very sure that investing more in inventories will help me to produce more products to make higher profit... Additionally, participant 8 indicated that; "I will heavily invest in working capital because having more goods can increase my profits margins Based on my observation, I attract more customers whenever I have enough goods and thus increase sales. But if I run out of goods my sales margin drops because my customers buy from other business". In this line participant 25 recounted incidents that necessitated overinvestment in working capital inventories and its expected impact on profitability as follows. "mostly if I don't have enough goods, the customers go different place to buy goods and that affect my sales and profit, but whenever I have substantial stock can attract a lot of customers which boost my sales revenue and profit...,"

Overinvestment in underinvestment SMEs: Although overconfident SME managers tends to overinvestment in inventory, the level of investment in underinvestment SMEs differs. As highly overconfident SME managers are more likely to invest more than $65 \%$ of their capital in inventory to create higher sales revenue to increase performance. In particular, participant 3, stated that:

"...For me, even though I believe that investing more in inventories can lead to more profits. I can only invest $70 \%$ of my money if have low inventory and use the $30 \%$ for other emergencies and daily operations. I will invest this amount based on my 17 years of experience in this business: wholesaling and retailing of used clothing". Another, participant 13, said that: "I think that buying more stock can help increase production, boost sales revenue and increase my profits margins. Based on my extensive knowledge of herbal medicine and previous performance, I will invest more than 65\% of my capital given that I don't have enough inventories at all, considering that fact this business requires huge investment to meet the market demand...".

Meanwhile, moderate overconfident SME managers wish to investment between $60 \%$ to $65 \%$ of any funds into inventory to maximize expected performance. In particular, participant 17 stated that:

"I will only invest about 60\% of my money if I do not have goods and use the rest for other emergencies. My experience is that if I have more goods, I can sell more and make more profits". Another, participant 9 said that "I can invest only $65 \%$ of any money into inventory if it is insufficient so that I can increase production, increase sales revenue and my profits margins. From my experience, the bakery and pastry business require a lot of capital, so it will help me meet market demand...". 
INTERNATIONAL JOURNAL OF ACADEMIC RESEARCH IN BUSINESS AND SOCIAL SCIENCES Vol. 10, No. 6, June, 2020, E-ISSN: 2222-6990 @ 2020 HRMARS

Moreover, low overconfident SME manager wish to allocate $55 \%$ to $60 \%$ of capital to inventory could be due low level of financial ability, industry experience and low perfect industry knowledge or low optimism in future growth expectation. Participant 11, stated that:

"...Well, I can invest up to 55\% of my money in inventory and use to remaining amount to take care of other emergencies. Even though I need more profits and understand the industry dynamic and business environment, I must take precaution in order not to lose a lot when the market demand is slow". Moreover, Participant 12 indicate that: "I can only spend 55-60\% of any money on goods and keep the rest for pressing issues and emergencies if demand is low. Of course, I have done this severally and realized my high profits...."

Overinvestment in Overinvestment SMEs: The study found overconfident SME managers in a firm with higher inventory investment are less likely to invest more since they are yet to reap expected returns. That means overconfident SME managers overinvestment is more acute to sales revenue volatility than non- overconfident managers. This evidence was captured by participant 11 who queried that:

".... Why should I buy more inventories if have more than enough to sell? I need to sell the current ones to realise my profit before I can replenish stock, else there is no need. On the other hand, if the current stock is not enough and have enough money, I will buy more inventories in order increase sales and make more profits. If I the have the money and I don't want to buy stock, then what is the essence of doing the business?". Likewise, participant 13 said that "I won't even think of buying more goods if I already have substantial stock. I need to recoup my investment and make profits before placing an order. Nonetheless, if don't have enough stock and have sufficient money I will buy much more stock in order to increase my sales revenue and profit margins. Similarly, it will be a bad decision that have insufficient inventories and yet have enough capital but unwilling to buy more stock, then why I am in business....?."

Working capital financing: Overconfident SME managers prefer internal sources of finance. Managers with enough capital are more likely to invest more in working capital inventory to increase performance. These managers view bank loan to be costly which will reduce expected profit margins. Even if they wish to use be bank loan, they do not have valuable assets to pledge as security. So, manager will prefer borrowing from family and friends if the need be. In view of these. Participants 1 further stated that:

"....... If I have enough money, I will buy more goods to increase sales and profit margins Based on my experience 10 years, having more goods attract more customers. But the bank will not help since I don't have collateral. And if the bank will, the interest rate is too high which will consume my profits. Moreover, the loan will not be sufficient. So, I prefer to use my own money instead". Similarly, Participant 7 added that: ... "I will use my own money or borrow from my friends, family members rather than borrow bank loan at a high cost which will "Chop" all my profits! Well if it interests free loan, then 
INTERNATIONAL JOURNAL OF ACADEMIC RESEARCH IN BUSINESS AND SOCIAL SCIENCES

Vol. 10, No. 6, June, 2020, E-ISSN: 2222-6990 @ 2020 HRMARS

good. I think that will be better. If not, I won't sacrifice my profits margin to pay high interest and be penniless...."

\section{Discussions}

SME managers' overconfidence behaviors show they can be better than their peers. This finding is consistent with prior studies on overconfidence (Svenson 1985; Malmendier \& Tate 2015; Ilieva et al., 2018). This means managers believe in their performance is above industry average and eager to invest more in working capital if they have enough. Although the result is similar to what previous studies found (Chen \& Hung Lin, 2013; Malmendier \& Tate, 2015) ours relate to investment in inventories.

Overconfident managers overinvest in working capital in inventory for higher profits is consistent with transactional motives; implying managers having more goods to can boost sales and profit margins. In addition, overinvestment in inventory provides accurate signal to the market; implying firms with more goods can attract more customers, increases sales and profitability. Lastly, overinvestment in inventory serves as a competitive tool for maintaining loyal customers and attracting potential customers, signifying that a firm with less goods are more likely to lose customers to their competitors, which overconfident managers view as a painful experience and potential loss of sales and profits. This result is similar to Deloof, 2003; Bhattacharya, 2008) but contradicts results of Pais \& Gama (2015); Lamptey et al., (2017). Meanwhile, in underinvestment company, highly overconfident SMEs managers would invest more than moderate overconfident manager and lowly overconfident managers for more profits. But, in overinvestment firms they are unwilling to overinvest in working capital inventory if expected sales are low, indicating that overconfident SME managers do have optimal inventory. Therefore, overconfident SMEs manager are more likely to overinvestment in working capital in inventory for higher profits in underinvested firms than overinvestment SMEs firms.

\section{Conclusion}

This study investigated overconfidence of SME managers in working capital management and performance. We conclude that SME managers are overconfident because of superior financial ability, complete industry knowledge and optimistic in business success believe to be better than industry average. So, they pursue aggressive working capital and financing; set level high performance and wish to increase working capital investment inventory if they have enough capital. Meanwhile low and moderate overconfident bias can reduce the risk seeking behaviors of highly overconfident SME managers due to the possibility sales revenue volatility. Conversely, overconfident SME managers can also enhance the risk averse behaviors of conservative SME manager having sufficient internal in order to improve firm performance through moderate inventory investment. Meanwhile, overconfident SME managers may have less or no financial risk as they prefer internal sources of finance to external to invest in working capital inventories, which can enhance their performance and owner's wealth respectively. Finally, overinvestment in inventories may allow managers to gain market leadership due to their perfect industry knowledge and optimism in business. Thus, we argue that it is not enough to study working capital and performance of SMEs without their overconfident bias. 
Our study makes a novel contribution as the first article to investigate overconfident bias in working capital management and performance by providing fresh empirical evidence on overconfident SMEs managers for development of literature. We also extend literature on managerial overconfident which primarily comes from managers of large firms. Again, we make new contributions to body of knowledge based on the evidence by demonstrating that: (1) overconfident SME managers influence working capital management and performance. Thus (1a) overconfident bias is more likely to influence working capital and performance of underinvestment SMEs; (b) Overconfident bias is less likely to influence working capital management and performance of overinvestment SMEs. That means the application of findings are relevant to all SMEs managers if they wish to maximize returns on working capital investment, particularly Ghanaian SMEs managers who believe that overconfident could be an alternative framework to better improve working capital and performance than applying of theories.

The implication of this result helps policy makers and regulators of SMEs to fashion out policies and programs to enhance SMEs financial management and practices. In addition, regulators should develop the capacity of SME managers on overconfidence framework as emerging paradigm in economic decision. Bank can factor behavioral bias in credit assessment by identify overconfident managers risk behaviors to tailor made credit and also minimize moral hazards. While government make conscious efforts to provide soft loans to such managers in order to increase performance and expedite SME growth to increase their contributions to GDP. In addition, this study provides knowledge to managers how their behaviors can negatively or positively decision and performance by prioritizing working capital inventory investment based on their overconfident levels to obtain the desire profits. Finally, we are constraint to generalize our results so future researcher to examine relationship between SMEs overconfident, working capital management and performance.

\section{References}

Bandara, R. M. S., \& Rathnasiri, U. A. H. A. (2016). The Working Capital Management Practices of Small and Medium Enterprises (SMEs) in Sri Lankall, ICME 2016, Faculty of Management and Finance, University of Ruhuna.

Barros, L, Silveira, A., (2008). Overconfidence, Managerial Optimism and The Determinants of Capital Structure. Brazilian Review of Finance ,6(3), 293-334.

Ben-David, I., Graham, J. R., \& Harvey, C. R. (2007). Managerial Overconfidence and Corporate Policies (No. w13711). National Bureau of Economic Research

Bertrand, M., \& Schoar, A. (2003). Managing with Style: The Effect of Managers on Firm Policies. The Quarterly Journal of Economics, 118(4), 1169-1208.

Bhattacharya, H. (2008). Theories of Trade Credit: Limitations and Applications. Available from: http://ssrn.com/abstract=1286443.

Brewerton, P. M., \& Millward, L. J. (2001). Organizational Research Methods: A Guide for Students and Researchers. Sage.

Burke, L. A., \& Miller, M. K. (2001). Phone Interviewing as a Means of Data Collection: Lessons Learned and Practical Recommendations. In Forum Qualitative Sozial for schung /Forum: Qualitative Social Research, 2(2), Art. 7. 
INTERNATIONAL JOURNAL OF ACADEMIC RESEARCH IN BUSINESS AND SOCIAL SCIENCES

Vol. 10, No. 6, June, 2020, E-ISSN: 2222-6990 @ 2020 HRMARS

Cachia, M., \& Millward, L. (2011). The Telephone Medium and Semi-Structured Interviews: A Complementary fit. Qualitative Research in Organizations and Management: An International Journal. 6(3) 265-277.

Chen, H. J., \& Lin, S. H. (2013). Managerial Optimism, Investment Efficiency, and Firm Valuation. Multinational Finance Journal, 17(3/4), 295-340.

Cooper, A. C., Woo, C. A., \& Dunkelberg, W. (1988), "Entrepreneurs Perceived Chances for Success," Journal of Business Venturing, 3, 97-108.

Creswell, J. W., \& David, J. C. (2018). Research Design: Qualitative, Quantitative, and Mixed Methods Approaches. (5th edn.). Los Angeles: SAGE. Publication.

Deakin, H., \& Wakefield, K. (2014). Skype Interviewing: Reflections of two PhD Researchers. Qualitative Research, 14(5), 603-616.

Deloof, M. (2003). Does Working Capital Management Affect Profitability of Belgian Firms? Journal of Business Finance and Accounting 30(3), 573-587.

Dyer, Jr. W. G., \& Wilkins, A. L. (1991). Better Stories, not Better Constructs, to Generate Better Theory: A Rejoinder to Eisenhardt. Academy of Management Review, 16(3), 613-619.

Eichholtz, P., \& Yönder, E. (2015). CEO Overconfidence, REIT Investment Activity and Performance. Real Estate Economics, 43(1), 139-162.

Etikan, I., Musa, S. A., \& Alkassim, R. S. (2016). Comparison of Convenience Sampling and Purposive Sampling. American Journal of Theoretical and Applied Statistics, 5(1), 1-4.

Fenig, S., Levav, I., Kohn, R., \& Yelin, N. (1993). Telephone vs face-To-face Interviewing in a community psychiatric Survey. American Journal of Public Health, 83(6), 896-898

Filbeck, G., \& Lee, S. (2000). Financial Management Techniques in Family Businesses. Family Business Review, 13(3), 201-216.

Fontana, F., \& Frey, J. (2000). The Interview: From Structured Questions to Negotiated text. In N. K. Denzin \& Y. S. Lincoln (Eds.), Handbook of Qualitative Research (pp. 645-672). Thousand Oaks, CA: Sage

French, K. R., \& Roll, R. (1986). Stock Return Variances: The Arrival of Information and the Reaction of Traders. Journal of financial economics, 17(1), 5-26.

Galasso, A., \& Simcoe, T. S. (2011). CEO Overconfidence and Innovation. Management Science, 57(8), 1469-1484.

Glogowska, M., Young, P., \& Lockyer, L. (2011). Propriety, process and purpose: Considerations of the Use of the Telephone Interview Method in an Educational Research study. Higher Education, 62(1), 17-26.

Hackbarth, D. (2008). Managerial traits and Capital Structure Decisions. Journal of financial and Quantitative Analysis, 43(4), 843-881.

Howorth, C., \& Westhead, P. (2003). The Focus of Working Capital Management in UK Small Firms. Management Accounting Research, 14(2), 94-111.

Ilieva, V., Brudermann, T., \& Drakulevski, L. (2018). "Yes, We Know!" (Over) Confidence in General Knowledge Among Austrian Entrepreneurs. PloS one, 13(5),1-15

Khoury, N. T., Smith, K. V., \& MacKay, P. I. (1999). Comparing Working Capital Management Practices in Canada, the United States and Australia: a note. Canadian Journal of Administrative Sciences 16 (1), 53-57. 
INTERNATIONAL JOURNAL OF ACADEMIC RESEARCH IN BUSINESS AND SOCIAL SCIENCES

Vol. 10, No. 6, June, 2020, E-ISSN: 2222-6990 @ 2020 HRMARS

Lamptey, L. L., Frimpong, K., \& Morrison, A. B. (2017). Empirical Study on the Influence of Working Capital Management on Performance of SMEs in a Developing Economy. Journal of Economics, Management and Trade,217(4) 1-10.

Langer, E. J. (1975). The Illusion of Control. Journal of Personality and Social Psychology, 32(2), 311.

Larwood, L. and Whittaker, W. (1977) Managerial Myopia: Self-Serving Biases in Organizational Planning, Journal of Applied Psychology 62(2), 194-98.

Larwood, L., \& Whittaker, W. (1977). Managerial Myopia: Self-serving Biases in Organizational Planning. Journal of Applied Psychology, 62(2), 194.

Malmendier, U., \& Tate, G. (2008). Who Makes Acquisitions? CEO Overconfidence and the Market's Reaction. Journal of Financial Economics, 89 (1), 20-43.

Malmendier, U., \& Tate, G. (2015). Behavioral CEOs: The Role of Managerial Overconfidence. Journal of Economic Perspectives, 29(4), 37-60.

Malmendier, U., Tate, G., \& Yan, J. (2011). Overconfidence and Early-Life Experiences: The Effect of Managerial Traits on Corporate Financial Policies. The Journal of Finance, 66(5), 1687-1733.

Merriam, S. B. (2009). Qualitative Case Study Research. Qualitative Research: A Guide to Design and Implementation, 39-54.

Pais, M. A., \& Gama, P. M. (2015). Working Capital Management and SMEs Profitability: Portuguese Evidence. International Journal of Managerial Finance.

Panpan, H., \& Xindong, Z. (2017). Can CEO Overconfidence Account for Enterprise R\&D Investment Distortion in the Case of Financing Constraint. Science \& Technology Progress and Policy, (2), 22.

Pham, N. L. (2013). Effective Working Capital Management in Small and Medium Enterprises in Vietnam (Doctoral dissertation, Dublin Business School)

Shelden, D. L., Angell, M. E., Stoner, J. B., \& Roseland, B. D. (2010). School Principals' Influence on Trust: Perspectives of Mothers of Children with Disabilities. The Journal of Educational Research, 103(3), 159-170.

Siggelkow, N. (2007). Persuasion with Case Studies. Academy of Management Journal, 50(1), $20-24$.

Spradley, J. (1979). Asking Descriptive Questions. The Ethnographic Interview, 1, 44-61.

Stake, R. (2000). Case Studies. In N. K. Denzin \& Y. S. Lincoln (Eds.), Handbook of Qualitative Research (pp. 435-454). Thousand Oaks, CA: Sage.

Strauss, A., \& Corbin, J. (1998). Basics of Qualitative Research: Techniques and Procedures for Developing Grounded Theory. Thousand Oaks, CA: Sage. (pp .11)

Svenson, O. (1981). Are we all Less Risky and More Skillful than Our Fellow Drivers? Acta Psychologica, 47(2), 143-148.

Trier-Bieniek, A. (2012). Framing the Telephone Interview as a Participant-centered Tool for Qualitative Research: A Methodological Discussion. Qualitative Research, 12(6), 630-644.

Vogl, S. (2013). Telephone Versus Face-to-Face Interviews: Mode Effect on Semi Structured Interviews with Children. Sociological Methodology, 43(1), 133-177.

Weinstein, N. D. (1980). Unrealistic optimism about future life events. Journal of personality and social psychology, 39(5), 806.

Yin, R. K. (1994). Discovering the Future of the Case Study. Method in Evaluation Research. Evaluation Practice, 15 (3), 283-290. 
INTERNATIONAL JOURNAL OF ACADEMIC RESEARCH IN BUSINESS AND SOCIAL SCIENCES Vol. 10, No. 6, June, 2020, E-ISSN: 2222-6990 @ 2020 HRMARS

\section{Appendices}

Appendix 1: Participants Demographic Data

\begin{tabular}{|l|l|}
\hline \multicolumn{2}{|l|}{$\begin{array}{l}\text { Table 1 } \\
\text { Participants Demographic }\end{array}$} \\
\hline Participants & Number \\
\hline Age & \\
\hline $25-40$ & 08 \\
\hline $41-50$ & 20 \\
\hline $51-60$ & 05 \\
\hline 61 -and above & 02 \\
\hline Gender & \\
\hline Male & 20 \\
\hline Female & 15 \\
\hline Education & \\
\hline Secondary & 06 \\
\hline Diploma & 05 \\
\hline Graduate & 12 \\
\hline Professional & 08 \\
\hline Master & 07 \\
\hline $\begin{array}{l}\text { Managerial Experience } \\
\text { (years) }\end{array}$ & \\
\hline $3-5$ & 05 \\
\hline $6-10$ & 09 \\
\hline $11-15$ & 13 \\
\hline $16-20$ & 06 \\
\hline 21 and above & 02 \\
\hline Industry & 12 \\
\hline Trading & 23 \\
\hline Manufacturing & \\
\hline & \\
\hline
\end{tabular}

